РЕАЛІЗАЦІЯ КОМПЕТЕНТНІСНОГО ПІДХОДУ У ПРОЦЕСІ САМОСТІЙНОЇ РОБОТИ ІНОЗЕМНИХ СТУДЕНТІВ У ВИВЧЕННІ ТЕКСТІВ ЗА ПРОФЕСІЙНИМ СПРЯМУВАННЯМ

\title{
IMPLEMENTATION OF COMPETENCE APPROACH IN THE PROCESS OF INDEPENDENT WORK OF FOREIGN STUDENTS IN THE STUDYING OF PROFILE ORIENTED TEXTS
}

у статmі розглядаються особливості організації самостійної роботи іноземних студентів у вивченні текстів за просресійним спрямуванням, досліджується сутність компетентнісного підходу, визначається його структура як взаємозв'язок когнітивного (знання), мотиваційного (урахування потреб, мотивів, пізнавальних інтересів), аксіологічного (мотиваційно-ціннісні ставлення й прагнення особистості до навчання, одержання ново інформаціі), емоційно-вольового (уміння саморегуляції, самоорганізації, дидактичної ресрлексії) складників. 3 урахуванням особливостей вивчення української мови як іноземної схарактеризовано дидактичну систему організації самостійної роботи студентів інженерних спеціальностей вищих навчальних закладів із використанням дидактичного пакета індивідуальних диференційованих завдань. Аналізуються завдання, які постають перед викладачами мовних дисциплін, що працюють з іноземними студентами. Розглядаються думки різних дослідників даної проблеми. Визначаються прийоми організації самостійноі роботи студентів інженерних спеціальностей вищих навчальних закладів на засадах компетентнісного підходу та подається опис вправ для формування й розвитку дискурсивного мовлення іноземних студентів під час вивчення текстів за професійним спрямуванням.

у статті наголошується, що активізація самостійної роботи студентів є одним із головних напрямів перебудови вищої освіти в Україні, ії національної стратегії модернізації освіти та підвищення якості просресійно підготовки. Крім того, висвітлено вимоги сучасних підручників до текстів для самостійного вивчення, у статті проаналізовано систему вправ для наукових текстів та прикладів завдань для самостійної роботи із профрільним текстом для іноземних студентів першого курсу. Окреслено перспективність подальших наукових пошуків у иьому напрямі. Матеріали статті можуть бути використані для позааудиторної роботи з іноземними студентами, що навчаються в Україні.

Ключові слова: компетентнісний підхід, самостійна робота, самоосвіта, тексти профресійного спрямування, іноземні студенти.

The article discusses the features of the organization of independent work of foreign students in the studying of profile oriented texts, explores the essence of the competency approach, defines its structure as a relationship of cognitive (knowledge), motivational (taking into account needs, motives, cognitive interests), axiological (motivational and value relations, the desire of the individual to learn, receive new information), emotional and volitional (skills of selfregulation, self-organization, didactic reflection) components. Taking into account the peculiarities of studying the Ukrainian language as a foreign language, the didactic system of organization of independent work of students - future engineers of higher educational institutions with the use of a didactic package of individual differentiated tasks is characterized. The tasks facing the teachers of language disciplines working with foreign students are analyzed. Opinions of various researchers of this problem are considered. The methods of organizing independent work of students-future enginners in higher educational institutions on the basis of the competence approach are defined and the description of exercises for formation and development of discursive speech of foreign students at studying of texts on a professional direction is given.

Materials of the article may be used for extracurricular activities for foreign students studying in Ukraine.

Activation of the independent work of students is one of the main directions of the restructuring of higher education in Ukraine, its national strategy for the modernization of education and improving the quality of vocational training. Furthermore, the requirements of modern textbooks for the texts for self-studying are highlighted and the system of exercises for scientific texts and examples of tasks for independent work with the profile oriented text for foreign students of the first course are analyzed in the article. The prospects of further scientific research in this direction are outlined. Materials of the article may be used for extracurricular activities for foreign students studying in Ukraine.

Key words: competence approach, selfstudying, independent work, profile oriented texts, foreign students.
Харківського національного

автомобільно-дорожнього університету
Постановка проблеми в загальному вигляді. Компетентнісний підхід $€$ важливим чинником забезпечення якісної профресійної підготовки орахівців, зорієнтованої на висококваліфрікованого, конкурентоспроможного випускника вищого навчального закладу. Компетентнісний підхід в освіті передбачає серйозні зрушення в розумінні її загальних цілей, узгодження світових освітніх систем в аспекті глобалізації з метою надання молоді можливості інтеграції в різні соціуми, самоактуалізації в різних умовах [1, с. 20]. Однією з найважливіших складових частин навчальної роботи в закладі вищої освіти (далі - 3ВО) є також самостійна робота студентів, активізація якої виступає одним 3 основних напрямів перебудови системи вищої освіти в Україні, її державної стратегії 3 модернізації освіти і підвищення якості просресійної підготовки фрахівців. Серед основних цілей 
навчання української мови як іноземної у ЗВО України $€$ процес фрормування творчої особистості фрахівця, здатного до самовдосконалення і самоосвіти. Реалізація компетентнісного підходу у процесі самостійної роботи студентів $€$ важливою ланкою в забезпеченні якісної та сучасної освіти.

Аналіз останніх досліджень і публікацій. Проблема компетентнісного підходу в освіті та питання організації самостійної навчальної діяльності студентів в умовах кредитно-модульної та рейтингової систем були об'єктом дослідження як вітчизняних (А. Алексюк, О. Біда, Н. Бойко, В. Буряк, С. Вітвицька, Л. Волошко, В. Ільченко, В. Кузь, О. Кучерявий, І. Левіна, О. Ляшенко, О. Савченко, М. Степко, В. Тюнін, М. Фібула, Я. Януш та інші), так і закордонних учених (В. Андреєв, В. Беловолов, І. Зимная, Б. Есипов, А. Козакова, Н. Коряковцева, Л. Кузнєцова, П. Лепін, І. Лернер, М. Махмутов, П. Підкасистий, Л. Холіна, T. Hill, R. Westbrook, H. Weilrich та інші). Роботи О. Коновала, О. Лаврентьєвої, О. Малихіна, Т. Туркот та інших дослідників присвячені доведенню важливості забезпечення в освітньому процесі вищої школи індивідуальної самостійної роботи студентів, перебудови її змісту та методик організації на компетентнісних засадах [5]. У цьому контексті зауважимо обґрунтування академіком І. Зязюном взаємозв'язку між компетентністю та самостійністю: «Компетентність як екзистенціальна властивість людини є продуктом власної життєтворчої активності людини, ініційованої процесом освіти» [2, с. 11].

Виділення не вирішених раніше частин загальної проблеми. Аналіз науково-педагогічної літератури свідчить про те, що серед методистів, викладачів 3 ВО та науковців відсутній єдиний погляд на те, що розуміється під самостійною роботою, немає єдиного визначення цього поняття, не окреслено функції і види самостійної роботи, шляхи підвищення ефективності самостійної роботи, а особливо - шляхи підвищення ефективності самостійної роботи іноземних студентів. Питання організації самостійної роботи під час вивчення текстів за професійним спрямуванням досі розглядалося фррагментарно й залишається дискусійним, тому огляд методології та використання компетентнісного підходу в навчальному процесі відповідатиме потребам іноземних студентів, що навчаються у технічних 3ВО, та забезпечуватиме реалізацію мовленнєвої діяльності на профресійному рівні. Недостатня розробленість теорії та технологій реалізації компетентнісного підходу у процесі вивчення фрілологічних дисциплін на інженерних фракультетах вишів визначила вектор наших наукових пошуків.

Мета статті. 3 огляду на вищезазначене сорормульована мета статті, яка полягає в теоретичному обґрунтуванні та висвітленні дидактичних аспектів розроблення та використання дидактич- них пакетів індивідуальних диференційованих завдань з української мови як іноземної як одного із засобів реалізації компетентнісного підходу у процесі самостійної роботи іноземних студентів.

Виклад основного матеріалу. Головною метою навчання у XXI ст. постає формування компетентної особистості, здатної конструктивно реалізувати власний творчий потенціал. Дослідники порівнюють традиційний та компетентнісний підхід до організації навчального процесу та підкреслюють, що традиційний підхід виходить з того, що особистісних результатів можна досягти набуттям необхідних знань, а компетентнісних - через набуття досвіду самостійного розв'язування проблем.

У роботі розглядаємо компетентність у галузі самостійної навчальної діяльності як універсальне поняття, як метауправління («мета-» - «над» Д. Р.) самостійними діями, адже в розвиненому вигляді воно інтегрує психолого-особистісні характеристики суб'єкта навчального процесу зі змістовим і процесуальним боком учіння. У нашому дослідженні ми поділяємо думку науковців, що стосовно майбутніх фахівців з вищою освітою компетентність «уміння вчитися» «дає змогу особистості, яка звикла вчитися самостійно, не губитися в пізнавальній і життєвій ситуації, не зупинятися, якщо немає готових рішень, не чекати підказки, а самостійно шукати джерела інформації, шляхи розв'язання проблеми, адже вміння вчитися змінює її стиль мислення і життя» [5, с. 86].

Сучасний контекст навчання 3 фаху поряд із розвитком фрахових та професійних компетенцій включає також розвиток компетенцій комунікативних, методичних і соціальних. Ключовими елементами вищеназваних компетенцій є стратегії учіння, найважливішою з яких $є$ самостійне читання іноземними студентами текстів за професійним спрямуванням. Значуща роль у самостійному вивченні текстів за професійним спрямуванням відводиться таким елементам, як: використання інтернаціоналізмів, власних назв, числівників, символів, виділень іншим шрифтом та ілюстрацій як «ключів» до розуміння; опора на фрахові знання, на структуру тексту; складання нотаток під час читання; розпізнавання стилів читання; розподіл тексту на сенсоутворюючі частини, відокремлення в них головної та другорядної інформації; звернення до словника лише тоді, коли 3 контексту не можна зрозуміти значення слова.

Отже, 3 опертям на окреслені сутність та вимоги компетентнісного підходу нами обґрунтована й апробується дидактична система організації самостійної роботи з української мови студентів інженерних спеціальностей вищих навчальних закладів із використанням дидактичного пакета індивідуальних диференційованих завдань. Індивідуальний дидактичний пакет для супроводу самостійної навчальної діяльності - це допоміжна 
система дидактичних матеріалів (у контексті нашого дослідження - $з$ української мови як іноземної - Д. Р.), призначених для самостійного опанування студентами знань і вмінь із навчальних дисциплін, орієнтованих на озброєння студентів методами самостійної навчальної діяльності, фрормування в них здатності до самонавчання й самоосвіти. Такий пакет пропонується студенту після вивчення кожної теми для закріплення матеріалу.

Елементами дидактичного пакета індивідуальних диференційованих завдань було визначено такі: 1. Окреслені викладачем дидактичні особливості теми, розділу, параграфрів, які пропонуються для самостійного вивчення. 2. Мета і завдання їх самостійного опрацювання, значущість самостійно опрацьованого матеріалу для вивчення інших навчальних дисциплін та майбутньої професійної діяльності. 3. Завдання для самостійного опрацювання теоретичного матеріалу 3 анотаціями викладача (тексти за професійним спрямуванням, студент має змогу обирати тексти $з$ декількох запропонованих). 4. Завдання для опрацювання текстів, які містять систему завдань різного рівня складності (запитання до текстів, вправи для вивчення та запам'ятовування нової лексики). 5. Творчі завдання, виконання яких оцінюється додатковими балами. 6. Інформація щодо оцінювання самостійно виконаних студентами завдань. 7. Завдання на дидактичну рефрлексію (виконання яких коментується викладачем усно, без виставлення оцінки балами). Виконання студентами диференційованих завдань передбачає можливість самостійного або за допомогою викладача вибору рівня його складності, відповідної прогнозованої оцінки. Залежно від потреб студентів їм можуть бути надані відповідні консультації та забезпечена дозована дидактична підтримка, що детермінується рівнем готовності студента до самостійної навчальної діяльності.

Викладачам, що працюють 3 іноземними студентами, варто пам'ятати, що більшість іноземних студентів не вміють самостійно працювати 3 науковими текстами, довідковою літературою, не вміють контролювати оцінювати результати своєї діяльності, нераціонально розподіляють і неекономно використовують час, відведений на самопідготовку. Система індивідуальних диференційованих завдань може виступати додатковою мотивацією для студентів під час вивчення української мови як іноземної.

Значуща роль у самостійному вивченні текстів за професійним спрямуванням відводиться також підготовці студентів до самостійної роботи. Авторам підручників варто пропонувати для самостійної роботи іноземних студентів будь-яку закінчену за смислом частину навчального посібника або текст зі спеціальною розробкою. Розробку повинен забезпечувати методичний апарат, що містить постановку завдань і орієнтовну основу; завдання для перевірки вивченого матеріалу; матеріал для контролю. Під час навчання студентів роботі з текстом важливо використовувати такі засоби для самостійної роботи: пам'ятки, рекомендації, інструкції, моделі, схеми. Ці засоби самостійної роботи позначають мету й умови роботи, пропонують оптимальну послідовність дій з осмислення прочитаного. Зміст цих завдань залежить від характеру текстового матеріалу, а також від рівня підготовленості студента до самостійної роботи з тим або тим текстом за професійним спрямуванням.

Система вправ до наукових текстів має бути побудована за принципом «від простого до складного», складатися із завдань, що включають:

1) завдання на пошук одиниць смислової інфрормації тексту;

2) завдання на скорочення тексту;

3) завдання на інтерпретацію прочитаного.

Л. Субота наводить такі приклади завдань для самостійної роботи з текстом за фрахом іноземних студентів І-го курсу: «1) виділення в тексті суттєвої інформації і скорочення деталей, які не несуть вагомого інфрормаційного навантаження; 2) розділення тексту на смислові частини, запис основної інорормації смислових частин у фрормі плану, простого, складного, тезисного; 3) зіставлення складеного плану з виділеними смисловими частинами; 4) визначення ключових понять за допомогою інфрормації з тексту; 5) складання схеми на основі прочитаного тексту; 6) підготовка повідомлення за складеною схемою, планом тексту; 7) виконання тестових завдань із читання за чітко визначеними часовими обмеженнями; 8) виконання завдань у тестовій фрормі для поточного, модульного, підсумкового контролів із читання за фрахом [4, с. 190].

Самостійна робота, на думку В. Козакова, дає знання, переконання і забезпечує найбільш високий рівень засвоєння, саме тому ця фрорма роботи $\epsilon$, поза сумнівом, ефективною, практичною та продуктивною фрормою навчання у фрормуванні особистості студента [3, с. 112]. Самоосвіта $€$ невід'ємною частиною систематичного навчання у ЗВО, сприяє поглибленню, розширенню й міцному засвоєнню знань.

Висновки. Отже, самостійне читання іноземними студентами текстів за професійним спрямуванням $є$ однією 3 найбільш ефективних стратегій вивчення української мови як іноземної. Самостійну роботу можна розглядати як обов'язковий вид навчальної діяльності студента і як ефективний спосіб навчання, незважаючи на складність і неопрацьованість багатьох її аспектів. У період рефрормування всіх ланок системи освіти України впровадження компетентнісного підходу має бути системним і багатовимірним процесом, який із позицій актуальних вимог суспільства до вищої 
школи стимулюватиме педагогів більш активно залучати здобувачів освіти до особистісно значущого й успішного навчання, що стане можливим за умови упровадження інноваційних дидактичних технологій. Активізація самостійної роботи 3 використанням компетентнісного підходу сприятиме посиленню активності іноземних студентів у вивченні навчального матеріалу, підвищенню ефрективності його засвоєння, фрормуванню вміння самостійно, систематично і методично правильно розширювати отримані знання, фрормуванню потреби в читанні літератури за фрахом.

Репрезентоване дослідження не вичерпує всього кола питань, пов'язаних із самостійною роботою іноземних студентів, що спричиняє необхідність подальших досліджень виокремленої проблеми та розроблення методичних рекомендацій щодо поліпшення організації самостійної роботи студентів, комплексів навчально-методичного забезпечення самостійної роботи студентів.

\section{БІБЛІОГРАФІЧНИЙ СПИСОК:}

1. Гриньова В. Модернізація національної освіти на засадах компетентнісного підходу : сутність і поняттєво-термінологічний апарат. Рідна школа. 2016. № 4. С. 20-23.

2. Зязюн І. Філософрія поступу і прогнозу освітньої системи. Педагогічна майстерність : проблеми, пошуки, перспективи : монографрія. Київ ; Глухів : РВВ ГДУ, 2005. 234 с.

3. Козаков В. Самостоятельная работа студентов и ее инорормационно-методическое обеспечение : учебное пособие. Киев : Вища школа, 1990. 246 с.

4. Субота Л. Самостійна навчальна діяльність іноземних студентів у вивченні текстів. Вісник Запорізького національного університету : збірник наукових статей. Серія «Педагогічні науки» / гол. ред. Л. Міщик. Запоріжжя : Запорізький національний університет, 2012. № 1 (17). С. 188-191.

5. Теорія і практика організації самостійної роботи студентів вищих навчальних закладів : монографрія / за ред. О. Коновала. Кривий Ріг : Книжкове видавництво Кирєєвського, 2012. 380 с. 